\section{1303 - Short stature, high productive potential and industrial quality}

\author{
Francisco de Assis Franco ${ }^{1}$, Volmir Sergio Marchioro ${ }^{1^{*}}$, \\ Tatiane Dalla Nora Montecelli ${ }^{1}$, Ivan Schuster ${ }^{1}$, Mateus Polo ${ }^{1}$, \\ Leandro Vagno Souza ${ }^{1}$, Fábio Junior Alcântara de Lima ${ }^{1}$, Adriel \\ Evangelista ${ }^{1}$, Diego Augusto dos Santos ${ }^{1}$ and Edson Luiz Grave ${ }^{1}$
}

\begin{abstract}
CD 1303 is a cultivar indicated for the wheat-producing regions 1, 2 and 3 of the states of Rio Grande do Sul, Santa Catarina and Paraná. It has an early cycle, a short stature and high productive potential (mean of $4311 \mathrm{~kg} \mathrm{ha}^{-1}$ ).
\end{abstract}

Key words: Triticum aestivum L., short cycle, short plant height.

\section{INTRODUCTION}

Wheat is one of the staple crops for human consumption, ranking among the three chief grain crops in the world. In the southern region of Brazil, mainly in the states of Paraná and Rio Grande do Sul, wheat cultivation is the basis of production and industrialization. In addition, wheat is an extremely important crop for the production system involving soybean and maize, mainly in southern Brazil.

To promote wheat cultivation and meet the demands of wheat producers, the wheat breeding program of COODETEC developed cultivars with high productive potential and high industrial quality. Simultaneously, a selection for improved agronomic performance is being developed (Franco et al. 2011, Franco et al. 2015, Marchioro et al. 2015). In continuation of the line of research targeting the selection of high-yielding cultivars, with short stature and high industrial quality, the wheat cultivar CD 1303 was developed.

\section{BREEDING METHODS}

Cultivar CD 1303 resulted from the cross of cultivars CD 150 and BRS 177, performed in Palotina in 2005 and F1 seeds were sown in the same year in a greenhouse, in Cascavel. The plants were harvested at maturity and all ears bulk-threshed, resulting in the F2 population. The F2 population was grown in a field in Palotina in 2006, using the modified mass method. This procedure consists of selecting the best plants within a population, threshing the ears of all selected plants together, and sowing a significant sample of these seeds on a plot with low density of individual plants to obtain the next generation. The F3 and F4 populations were cultivated by the above method in Palotina, in 2007 and 2008. In 2009, the F5 population was grown in Palotina by the genealogical method. This procedure consists of selecting plants, threshing the ears of the selected plants together and sowing the seeds of each plant in the next generation in a plot with low density of individual plants. The F6 population was also selected in the field by the genealogical method in Palotina, in 2010. At this
Crop Breeding and Applied Biotechnology 18: 123-125, 2018 Brazilian Society of Plant Breeding. Printed in Brazil http://dx.doi.org/10.1590/198470332018v18n1c15 \title{
.
}


stage, the traits of several sibling lines had become fixed, and one line (line CD 12223) was selected, from which CD 1303 (pedigree CC18815-00P-00P-10P-4P-OP) was derived

\section{TRAITS AND PERFORMANCE}

Line CD 12223 was included in the HC (Hot/Cold) genotype collection in 2011, and was assessed in 2012, in Preliminary tests in Cascavel/PR, Palotina/PR, Guarapuava/ $P R$, Não Me Toque/RS, and in São Gotardo/MG, where the yields exceeded those of the controls. The VCU trials of 2013-2015 were distributed at different locations of the wheat-producing regions and in different seasons (Table 1). The experiment was arranged in a randomized block design, with three replications in plots with six 5-m long rows, spaced $0.17 \mathrm{~m}$ apart. Fertilization and disease, pest and weed control were applied according to the official technical recommendations (Comissão 2013). Prior to sowing, the seeds were treated with Triadimenol + Imidacloprid.
Table 1. Locations and seasons of evaluations of Value for Cultivation and Use (VCU) of cultivar CD 1303, in the wheat-growing regions 1, 2 and 3, including the states of Rio Grande do Sul, Santa Catarina and Paraná, from 2013 to 2015

\begin{tabular}{lccc}
\hline Region/Location & $\mathbf{2 0 1 3}$ & $\mathbf{2 0 1 4}$ & $\mathbf{2 0 1 5}$ \\
\hline Wheat-growing region 1 & 5 & 7 & 5 \\
\cline { 2 - 4 } Não Me Toque/RS & 2 & 2 & 1 \\
Vacaria/RS & - & - & 1 \\
Campos Novos/SC & 1 & 1 & 1 \\
Castro/PR & - & 1 & - \\
Guarapuava/PR & 2 & 2 & 2 \\
Ponta Grossa/PR & - & 1 & - \\
\hline Wheat-growing region 2 & 6 & 8 & 6 \\
Santo Augusto/RS & 1 & 2 & 2 \\
São Luiz Gonzaga/RS & - & 1 & 1 \\
Abelardo Luz/SC & 2 & 2 & - \\
Cascavel/PR & 3 & 3 & 3 \\
\hline Wheat-growing region 3 & 2 & 4 & 4 \\
Palotina/PR & 2 & 4 & 4 \\
\hline
\end{tabular}

The variables measured in the VCU tests were grain yield, days from emergence to heading, days from emergence to maturity, plant height, lodging, hectoliter weight, 1000-grain weight, pre-harvest sprouting, and tolerance to soil aluminum. The grains of three replications per treatment were mixed, generating composite samples, including quality analyses, thereby obtaining the variables: falling number, gluten strength and alveograph tenacity/extensibility ratio; farinograph stability; and flour color. The latter was determined by the $L * a * b *$ system, which is an international standard for colour measurements, by which the values of $L$ (lightness) vary from 0 (black) to 100 (white) and the a and $b$ values (chromaticity coordinates) range from -a (green) to $+a$ (red) and from - $b$ (blue) to $+b$ (yellow). At strategic locations, the genotypes included in the VCU tests were grown together without disease control, and the diseases leaf rust, leaf spot, powdery mildew, fusarium head blight, blast and mosaic virus were evaluated, among others.

The plant height of cultivar CD 1303 is short $(69 \mathrm{~cm})$, ranging from 58 to $84 \mathrm{~cm}$. The cycle is early (55-79 days from emergence to heading; 106-139 days from emergence to maturity). The averages of these characteristics in the wheatgrowing regions 1 and 2 were 69 and 124 days and in wheat-growing region 3 the means were was 65 and 117 days, respectively, varying according to the climatic conditions, sowing times and soil type.

CD 1303 has spindle-shaped ears, in upright to intermediate position. It was classified as moderately resistant to lodging, moderately susceptible to pre-harvest sprouting and moderately tolerant to soil aluminum. The mean hectoliter weight was $79 \mathrm{~kg} \mathrm{hL}^{-1}$ and 1000-grain weight 34 grams.

In the genotype sets tested in VCU evaluations at specific locations from 2013 to 2015 without disease control, information was obtained for the classification of cultivar CD 1303 with regard to the reaction to the main diseases. The cultivar was classified as moderately resistant to powdery mildew (Blumeria graminis f.sp. tritici), leaf rust (Puccinia triticina), blast (Pyricularia grisea) and wheat mosaic virus (soil-borne wheat mosaic virus) and moderately susceptible to scab (Fusarium graminearum), leaf spots (Septoria tritici and Bipolar sorokiniana), and glume blotch (Septoria nodorum).

In the analysis of processing quality of 16 samples of the experiments conducted from 2013 to 2015 in the wheatgrowing regions 1, 2 and 3, a mean gluten strength (W) of $305 \times 10^{-4}$ joules and mean stability of 16.5 min were found, classifying CD 1303 in the groups of bread wheat cultivars (Table 2). The industrial quality of wheat cultivar CD 1303 is equal to or higher than that of the cultivars released early in Brazil (Franco et al. 2014, Marchioro et al. 2014, Scheeren et al. 2014, Franco et al. 2015)

The grain yield means of cultivar CD 1303 in the wheat-growing regions 1, 2 and 3 were 1\%,5\% and 1\% higher than those of the controls, respectively (Table 3). The overall grain yield mean was $4.311 \mathrm{~kg} \mathrm{ha}^{-1}$, exceeding the controls by $3 \%$. In view of the grain yield performance of cultivar CD 1303, it was indicated for cultivation in the wheat-growing 
Table 2. Means of general gluten strength (W), yield stability (YS), falling number (FN), tenacity/extensibility ratio (P/L), flour color (COL L, COL a and COL b) per wheat-growing region in samples of tests conducted in the states of Rio Grande do Sul, Santa Catarina and Paraná, from 2013 to 2015

\begin{tabular}{lcccccccc}
\hline Wheat-growing region & No of samples & $\begin{array}{c}\mathbf{W} \\
\left(\times 10^{-4} \mathrm{~J}\right)\end{array}$ & $\begin{array}{c}\text { YS } \\
(\mathrm{min})\end{array}$ & $\begin{array}{c}\mathbf{F N} \\
(\mathrm{min})\end{array}$ & $\begin{array}{c}\mathbf{P} / \mathbf{L} \\
\text { (ratio) }\end{array}$ & $\begin{array}{c}\text { COL L } \\
(89 \text { to 96) }\end{array}$ & $\begin{array}{c}\text { COL } \mathbf{a} \\
(-1 \text { to }+1)\end{array}$ & $\begin{array}{c}\text { COL } \mathbf{b} \\
(6 \text { to } 10)\end{array}$ \\
\hline 1 & 5 & 288 & 15.7 & 335 & 1.19 & 92.4 & -0.3 & 10.9 \\
2 & 6 & 316 & 17.6 & 377 & 1.15 & 92.3 & -0.4 & 11.4 \\
3 & 5 & 331 & 16.1 & 332 & 1.19 & 92.4 & -0.1 & 11.0 \\
\hline Mean & - & $\mathbf{3 1 2}$ & $\mathbf{1 6 . 5}$ & $\mathbf{3 4 8}$ & $\mathbf{1 . 1 8}$ & $\mathbf{9 2 . 4}$ & $-\mathbf{0 . 3}$ & $\mathbf{1 1 . 0}$ \\
\hline
\end{tabular}

Table 3. Grain yield means $\left(\mathrm{kg} \mathrm{ha}^{-1}\right)$ of cultivar CD 1303 and the controls in the tests carried out in the wheat-growing regions 1,2 and 3, including the states of Rio Grande do Sul, Santa Catarina and Paraná, from 2013 to 2015

\begin{tabular}{|c|c|c|c|c|c|c|}
\hline Wheat-producing region & Cultivar & 2013 & 2014 & 2015 & Mean & (\%) \\
\hline \multirow{4}{*}{1} & CD 1303 & 5768 & 6007 & 4267 & 5365 & 101 \\
\hline & $\mathrm{C}_{1}$ & 5883 & 5911 & 4242 & 5345 & 101 \\
\hline & $\mathrm{C}_{2}$ & 5796 & 6027 & 4038 & 5287 & 99 \\
\hline & $C_{M}$ & 5840 & 5969 & 4140 & 5316 & 100 \\
\hline \multirow{3}{*}{2} & CD 1303 & 5504 & 5001 & 5433 & 5313 & 105 \\
\hline & $\mathrm{C}_{1}$ & 5408 & 4762 & 4743 & 4971 & 99 \\
\hline & $\mathrm{C}_{\mathrm{M}}$ & 5259 & 4978 & 4879 & 5038 & 100 \\
\hline \multirow{4}{*}{3} & CD 1303 & 1134 & 3314 & 2317 & 2255 & 101 \\
\hline & $\mathrm{C}_{1}$ & 1274 & 3212 & 2240 & 2242 & 100 \\
\hline & $\mathrm{C}_{2}$ & 1086 & 3278 & 2314 & 2226 & 100 \\
\hline & $C_{M}$ & 1180 & 3245 & 2277 & 2234 & 100 \\
\hline
\end{tabular}

$C_{M}=$ Control means. Controls $C_{1}$ and $C_{2}$ were, respectively, the cultivars BRS Guamirim and Quartzo in 2013, and CD 1440 and TBIO Sinuelo in 2014 and 2015.

regions listed above, for the states of the Southern Region of Brazil. The cultivar was registered by the Registro Nacional de Cultivares ( $\left.n^{\circ} 35804\right)$. Cultivar CD 1303 belongs to the bread/strong wheat class, with high grain productive potential and short stature, representing a promising option for farmers of Rio Grande do Sul, Santa Catarina and Paraná.

\section{BASIC SEED PRODUCTION}

The COODETEC Desenvolvimento, Produção e Comercialização Agrícola Ltda (BR 467 - km 98 - PO Box 89 - CEP. 85813-450, Cascavel, Paraná, Brazil), is authorized to license seed companies to produce protected varieties (law no 9456/97), to multiply and sell seed to grain producers. Cultivar CD 1303 was released on the market in 2017, with an availability of five thousand $40 \mathrm{~kg}$ bags of seed.

\section{REFERENCES}

Comissão Brasileira de Pesquisa de Trigo e Triticale (2013) Informações técnicas para trigo e triticale - safra 2013. Instituto Agronômico do Paraná, Londrina, 220p.

Franco AF, Marchioro VS, Dalla Nora T, Oliveira EF, Schuster I, Vieira ESN, Sobrinho AA and Evangelista A (2011) CD 150 - short wheat cultivar with high quality and high yield. Crop Breeding and Applied Biotechnology 11: 186-188.

Franco AF, Marchioro VS, Schuster I, Dalla Nora T, Lima FJA, Evangelista A, Polo M and Prado CM (2014) CD 122 - Bread wheat, suitable for cultivation across southern Brazil. Crop Breeding and Applied Biotechnology 14: 136-138.

Franco AF, Marchioro VS, Schuster I, Dalla Nora T, Polo M, Lima FJA,
Evangelista A and Santos DA (2015) CD 1550 - bread wheat, cultivar with high gluten strength for the cooler regions of Brazil. Crop Breeding and Applied Biotechnology 15: 48-50.

Marchioro VS, Franco AF, Schuster I, Dalla Nora T, Lima FJA, Evangelista A, Polo M and Santos DA (2014) CD 122 - Bread wheat, suitable for cultivation across southern Brazil. Crop Breeding and Applied Biotechnology 14: 270-272.

Marchioro VS, Franco AF, Schuster I, Dalla Nora T, Lima FJA, Polo M and Evangelista A (2015) CD 154: Strong gluten wheat with high productive potential. Bioscience Journal 31: 1304-1306.

Scheeren PL, Caetano VR, Caierão E, Silva MS, Nascimento Junior A, Eichelberger L, Miranda MZ and Brammer SP (2014) BRS 328 Double haploid bread wheat cultivar. Crop Breeding and Applied Biotechnology 14: 65-67.

(c) $\mathrm{EY}$ This is an Open Access article distributed under the terms of the Creative Commons Attribution License, which permits unrestricted use, distribution, and reproduction in any medium, provided the original work is properly cited. 